\title{
BOOBY II, A QUANTITATIVE NEUSTON SAMPLER FOR USE FROM SMALL BOATS
}

AUTHOR(S):

Bieri, Robert; Newbury, Thomas K.

CITATION:

Bieri, Robert ... [et al]. BOOBY II, A QUANTITATIVE NEUSTON SAMPLER FOR USE FROM SMALL BOATS. PUBLICATIONS OF THE SETO MARINE BIOLOGICAL LABORATORY 1966, 13(5): 405-410

ISSUE DATE:

1966-02-25

URL:

http://hdl.handle.net/2433/175415

RIGHT: 


\title{
BOOBY II, A QUANTITATIVE NEUSTON SAMPLER FOR USE FROM SMALL BOATS
}

\author{
Robert BIERI and Thomas K. NEWBURY ${ }^{1)}$ \\ Antioch College, Yellow Springs, Ohio, U.S.A.
}

With 4 Text-figures and 1 Table

DAvid $(1963,1965)$ described a large neuston sampler based on the principle of the otter-board and has reviewed earlier neuston sampling devices. See also CASSIE (1963) and BANSE (1964) for a discussion of other neuston sampling devices, methods and theory. DAvid has used his sampler successfully from the R.R.S. Discovery at speeds up to six knots. RICHARDS and Sund of the U.S. Fish and Wildlife Service (personal communication) have modified DaviD's net with larger runners and vanes and have towed it at speeds up to nine knots to catch small fish and squids in the surface layer.

During Cruise 7 of the R/S Te Vega of Stanford University, we had an opportunity to study the neuston of the western equatorial Pacific. Because much of our work in lagoons and bays was done from small boats, we built a small neuston sampler. Its chief advantages are: 1 . The net is carried well forward of the otter-board platform so that there is little if any disturbance of the water in front of the net. 2. The net tows well outside the wake of the towing boat or ship. 3. The depth of fishing can be quickly adjusted for studies of micro-vertical distribution. 4. The net has a flow meter so that both volume of water filtered and sea surface skimmed can be calculated. 5 . The sampler is inexpensive and can be handled by one person in a small boat.

\section{DESCRIPTION OF THE SAMPLER}

The design of the net is shown in Fig. 1. A list of materials is given in Table 1. It consists of three parts, a wooden platform, a metal net frame, and a nylon net with flow meter. The net platform is constructed of $1 \mathrm{~cm}$ ( $3 / 8$ inch) thick waterproof marine plywood and is joined together with screws and waterproof glue. Two wire loops, each twisted with a brass rod,

1) Present address: Marine Science Center, McGill University, Montreal 2, Canada.

Publ. Seto Mar. Biol. Lab., XIII (5), 405-410, 1966. (Article 22) 
TABLE I. BOOBY II, List of Materials.

Marine plywood, $8 \mathrm{~mm}\left(3 / 8^{\prime \prime}\right)$ thick:

\begin{tabular}{cll} 
Number of pieces & \multicolumn{1}{c}{ Dimensions } & \multicolumn{1}{c}{ Use } \\
1 & $\begin{array}{c}61 \mathrm{~cm} \times 92 \mathrm{~cm} \\
\left(24^{\prime \prime} \times 36^{\prime \prime}\right)\end{array}$ & Planing board \\
& $16.5 \mathrm{~cm} \times 121 \mathrm{~cm}$ & Side boards, curved at one \\
2 & $\left(6.5^{\prime \prime} \times 47.5^{\prime \prime}\right)$ & end \\
& $61 \mathrm{~cm} \times 15.5 \mathrm{~cm}$ & $\begin{array}{l}\text { Bow crossmember and stern } \\
\text { depressor }\end{array}$ \\
2 & $\left(24^{\prime \prime} \times 6^{\prime \prime}\right)$ & Otterboards \\
& $42 \mathrm{~cm} \times 37 \mathrm{~cm}$ &
\end{tabular}

Brass rod, $8 \mathrm{~mm}\left(3 / 8^{\prime \prime}\right)$ diameter :

$\begin{array}{lll}1 & 155 \mathrm{~cm}\left(61^{\prime \prime}\right) \text { long } & \text { Upper net frame rod } \\ 1 & 105 \mathrm{~cm}\left(41.5^{\prime \prime}\right) \text { long } & \text { Lower net frame rod } \\ 2 & 35 \mathrm{~cm}\left(13.75^{\prime \prime}\right) \text { long } & \text { Net frame braces } \\ 2 & 80 \mathrm{~cm}\left(31.5^{\prime \prime}\right) \text { long } & \text { Otterboard braces }\end{array}$

Miscellaneous :

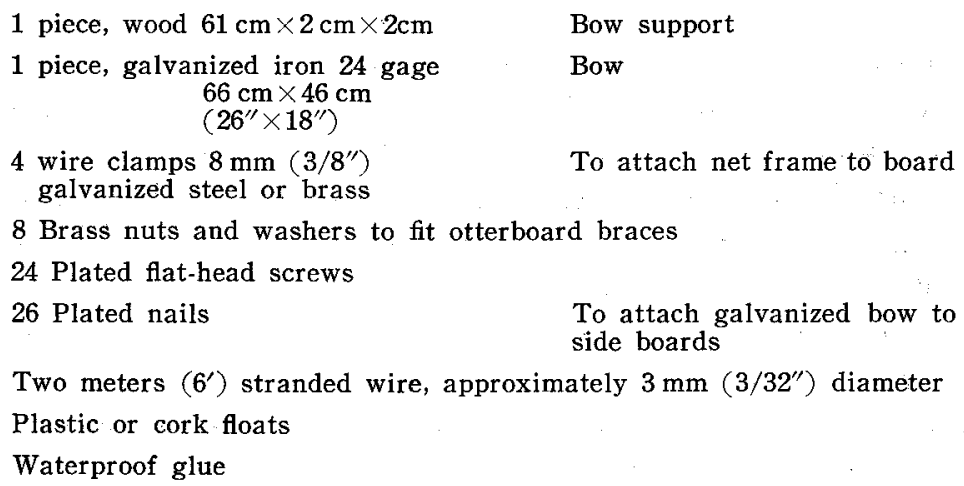

pull the sides in against two $15.5 \mathrm{~cm}$ ( 6 inch) wide cross frames during the assembly and are left in for additional strength.

The net frame is made of $8 \mathrm{~mm}(3 / 8 \mathrm{inch})$ diameter brass rod and is held to the wood platform with four standard $3 / 8$ inch "U-shaped" wire clamps. The front of the platform is made of number 24 gage galvanized sheet iron nailed to the side pieces. Styrofoam plastic was added inside the platform to prevent swamping in heavy seas, although any light floating material such as cork could be used. Note that channels are left along the sides of the styrofoam to allow for water drainage. Any desired net can be used on the net frame.

\section{OPERATION OF THE SAMPLER}

The sampler has a three-piece bridle of plastic line attached by figureeight knots through the holes shown in Fig. 1. The length of the bridle 


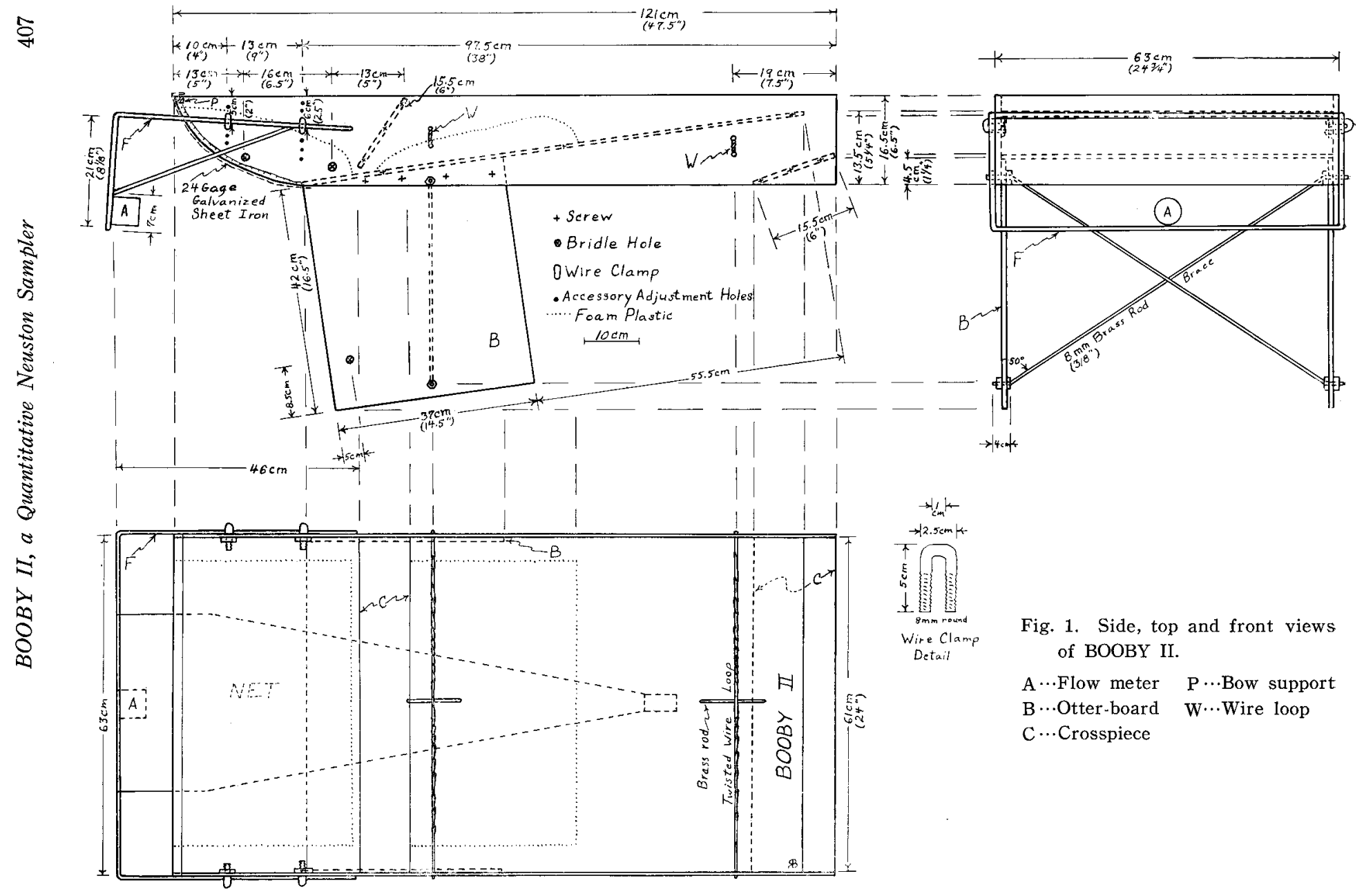




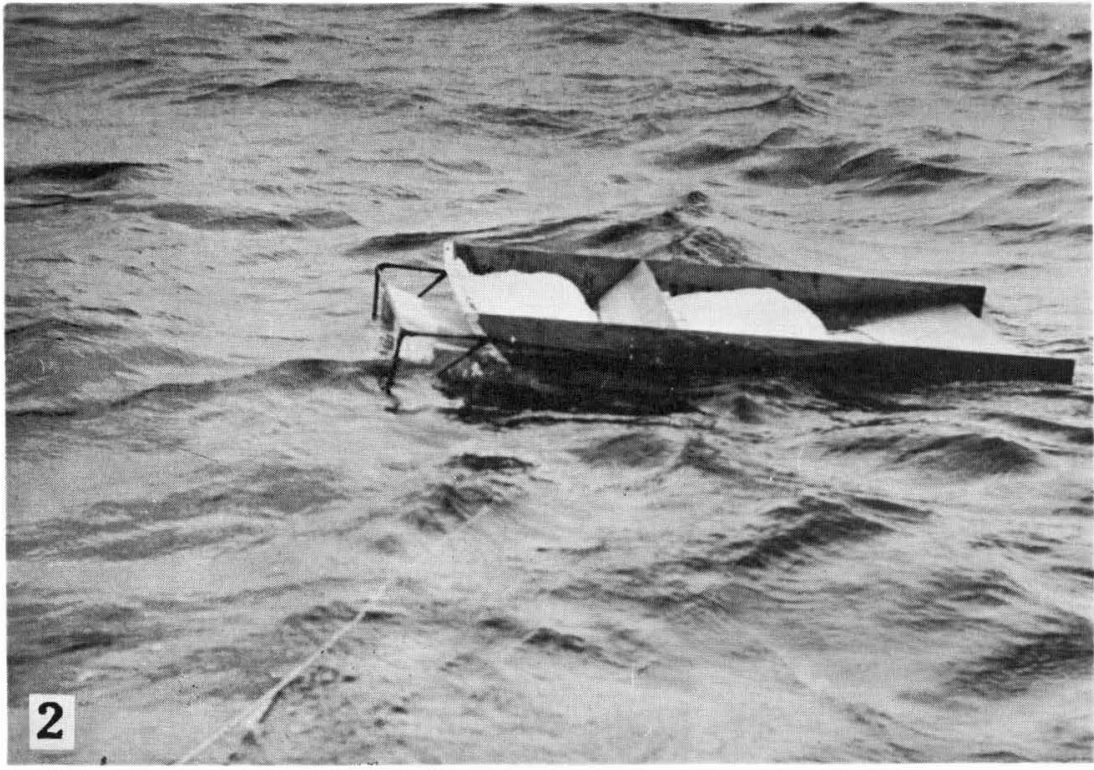

Fig. 2. BOOBY II towed from a 4.4 meter $\left(14^{\prime}\right)$ long boat. Note the sheet metal bow, styrofoam plastic and accessory holes used to adjust the depth of the net.

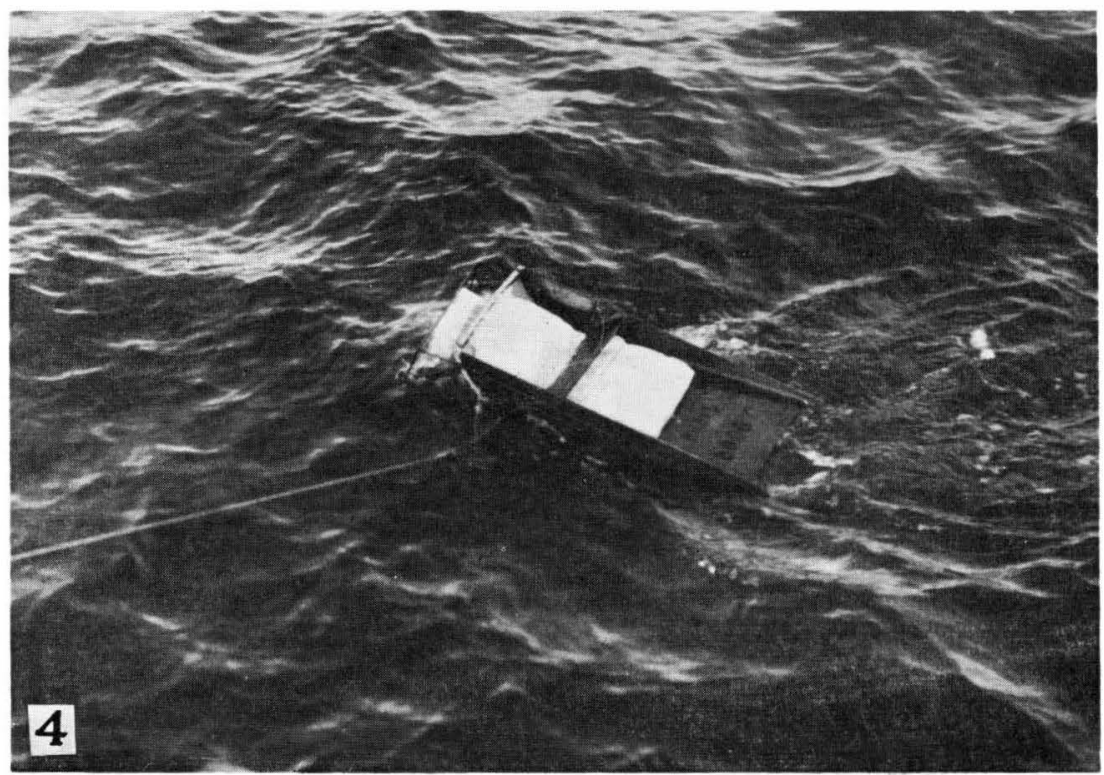

Fig. 4. BOOBY II towed from the $\mathrm{R} / \mathrm{S}$ Te Vega. Note the bridle attachment and the accessory wire used to haul the platform on board with a boat hook, 
must be adjusted by trial and error, but in our model the upper two lines were $30 \mathrm{~cm}$ long and the lower line $45 \mathrm{~cm}$ long. After the cod-end is firmly attached and the flow meter zeroed, the net is lowered or thrown into the water and towed at one to three knots. When working from a 4.4 meter (fourteen-foot) boat with a ten horsepower outboard motor, the net clears the wake of the boat by two or three meters when the towing line is attached to the bow of the boat (Fig. 2). No davits or winches are needed. In towing BOOBY II from the 43 meter (135 foot) long Te Vega, we used about 20 meters of plastic line run through a snatch block at the bow of the ship. If the ship rolls heavily, a two meter long rubber shock cord attached between the ship and the towing line (Fig. 3) helps steady the net.

Two of us were able to haul the net in by hand when towed at two to 2.5 knots. Fig. 4 shows BOOBY II being used at sea from $\mathrm{R} / \mathrm{S}$ Te Vega.

In our work in the waters between Fiji and Samoa, we caught a great variety of animals including Porpita, Velella, colonial Radiolaria, Trichodesmium, Coscinodiscus, blue pontellid copepods, Foraminifera, and chaetognaths. At night in bays and lagoons many bottom animals were caught in addition to the usual surface forms. These included a flatfish larva $4 \mathrm{~cm}$ long, blue and maroon colored ostracods, mysids, shrimps, decapod larvae of various sorts, stomatopod larvae and so forth. In the open sea we towed the net for one-half hour and with a net that filled half the net frame, filtered on the average about 40 cubic meters of water from 400 square meters of sea surface. At the Seto Marine Biological Laboratory on a similar model of BOOBY II we have used a

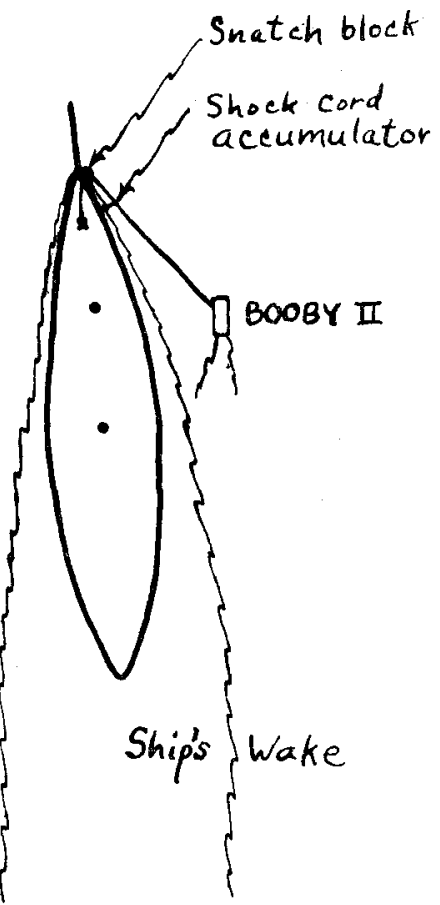

Fig. 3. Top view diagram showing the method used to tow BOOBY II from the $\mathrm{R} / \mathrm{S}$ Te Vega. net $63 \mathrm{~cm}$ wide, $20 \mathrm{~cm}$ deep and $100 \mathrm{~cm}$ long. This net, made of number 54 nylon grit gauze, filters about 75 cubic meters of water and skims about 750 square meters of sea surface in 30 minutes. When used in richer waters near shore, tows of 10 to 15 minutes catch adequate amounts of zooplankton for quantitative study.

We wish to thank Professor Rolf Bolin, leader of Te Vega 7 for his encouragement in this project. Captain JACK ThомSEN and Chief Engineer 
Roderick Gird helped us with part of the construction, and Maria Ferraro, James Collinson, Lawrence Jahn, and Darrell Halverson helped us operate BOOBY II, often under adverse conditions of rain, wind and sea. To them we offer our sincere thanks. This work was supported by NSF contract No. G 17465, and a grant from the Antioch College Faculty Research Fund.

\section{REFERENCES}

BANSE, K. (1964): On the vertical distribution of zooplankton in the sea. Progr. Oceanogr., Vol. 2 : pp. $55-125$.

CASSIE, R. M. (1963): Microdistribution of plankton. Oceanogr. Mar. Biol. An. Rev., Vol. 1 : pp. 223-252.

David, P. M. (1963): The neuston net, a device for sampling the surface fauna of the ocean. Natl. Inst. Oceanogr. Internal Rept. No. B 3 : pp. 1-5.

(1965): The surface fauna of the ocean. Endeavour, Vol. $24:$ pp. 95-100. 